\title{
Decomposition Characteristics of Selected Solid Organic Wastes by Black Soldier Fly (BSF) Larvae as Affected by Temperature Regimes
}

\author{
Arief Sabdo Yuwono ${ }^{1 *}$, Idat Galih Permana ${ }^{2}$, Lia Nurulalia ${ }^{3}$, \\ Priscilia Dana Mentari ${ }^{4}$
}

${ }^{1}$ Dept. of Civil and Environmental Engineering, IPB University, PO. Box 220 Bogor 16002, Indonesia ${ }^{2}$ Dept. of Nutrition and Feed Technology, IPB University, Jl. Agatis, Kampus IPB Darmaga, Bogor 16680, Indonesia ${ }^{3}$ Dept. of Plant Protection, IPB University, Jl. Kamper, Kampus IPB Darmaga, Wing 7 Level 5. 16680, Indonesia

${ }^{4}$ Dept. of Natural Resources and Environmental Management Sciences, IPB University, Bogor 16680, Indonesia

Received: 13 October 2020

Accepted: 21 December 2020

\begin{abstract}
This study aims to assess the decomposition characteristics of selected organic solid waste using Black Soldier Fly (BSF) larvae as affected by temperature regimes. Three types of waste were those originating from a restaurant, a traditional market, and a bread factory. Three temperature regimes (low, moderate, and high) were set up as it represents the Indonesian climate. The larvae flour resulted from the organic waste decomposition was tested as a protein source for day-old chicken (DOC) broiler to test the degree of palatability, whereas the compost quality was analysed according to the national standard. The results of the experiment indicated that the best waste reduction percentage was found at low temperature with a reduction percentage of $91.2 \%$. Wet base protein contents ranged from 8.9$17.1 \%$, where the highest content was found from the moderate temperature regime. The highest waste reduction index was found in restaurant waste, i.e. 4.33\%/day. The highest dry matter consumption rate was obtained from restaurant waste, i.e. $39.65 \mathrm{mg} / \mathrm{larvae} /$ day. The palatability index of BSF larvae flour to DOC broiler chickens generates preference number one among other feeds with average daily consumption of $8.0 \mathrm{grams} /$ head/day. The compost quality resulted from the organic waste decomposition process met the Indonesian standard, except the $\mathrm{C} / \mathrm{N}$ ratio.
\end{abstract}

Keywords: black soldier fly larvae, compost; decomposition, palatability index, protein

*e-mail: arief.sabdo.yuwono66@gmail.com 


\section{Introduction}

Waste is seen as unused goods with low economic value. It is due to the minimal benefits of organic waste management [1]. Urban solid waste management has emerged as a significant challenge not only because of health factors, but also environmental factors due to a large amount of waste produced [2]. Without proper management, waste could create several environmental problems.

For Indonesia, where the most significant part of the generated solid waste is an organic fraction, composting could be the best low-cost alternative solution to overcome this problem. During composting, conversion and degradation of organic matter are carried out by many microbial communities such as bacteria, fungi and actinomycetes. The mesophilic and thermophilic phases influence microbial activity during the composting process [3].

One technology to reduce organic waste is to make use of the decomposition process, where microorganisms can carry out the decomposition process within the material itself with the help of oxygen [4]. Another way to treat organic waste is the use of black soldier fly (BSF) larvae as decomposers of organic material [5-7]. $\mathrm{BSF}$ is known to be able to degrade organic waste by utilising larvae that extract energy and nutrients from vegetable waste, food scraps, animal carcasses, and faeces as food [8].

BSF larvae can eat a variety of food with differing flavours. BSF larvae can be given a variety of feed, including kitchen waste, fruits, vegetables, liver, fish waste, urban waste, human waste, as well as animal waste. Differences in feed can affect the development process of BSF larvae. Therefore, the right formulation is needed in feeding BSF larvae to maximize production and process efficiency. Some microbes that are used as a pre-treatment process can improve the digestive ability of BSF larvae, the process of larval development, and increase the mass of the pre-pupa stage [9].

BSF larvae have the best decomposition ability as compared to other organisms and microorganisms [10]. BSF larvae can reduce waste up to $50-80 \%$ (wet basis) of the total waste given [11]. Therefore, domestic waste can be appropriately handled and naturally using BSF larvae as decomposers [12]. The BSF larvae product can also be an essential component of animal feed (poultry, cultured fish, and ruminants) because of their relatively high protein content [13]. Beside BSF larvae product, bioconversion of organic solid waste by using BSF larvae can also produce compost [14]. The protein source of BSF larvae used for animal feed is a good alternative feed [15] since larval protein levels can reach up to $40 \%$ [16].

The objectives of the research are as follows:

1. To analyze the decomposition parameters of the BSF larvae as affected by temperature regimes and different types of waste source.
2. To measure the protein content of BSF larvae gained from different waste types and temperature regimes.

3. To assess the palatability of BSF larvae flour as compared with commercial feed on broiler day old chicken (DOC).

\section{Material and Methods}

This research was conducted in June 2019-January 2020, where the decomposition process was undergone in Bogor Municipality. The waste used originates from the Dramaga traditional market, restaurants, and one bread factory in West Java Province. The protein percentage of BSF larvae and quality of compost resulted from the decomposition process were analysed in Environmental Laboratory of SEAMEO BIOTROP, Bogor. The research instruments used in the experiment were wet bulb and dry bulb thermometers (range $0-100^{\circ} \mathrm{C}$ ), hammer, measuring band, saw, analytical balance $(0.1 \mathrm{gr})$, hand gloves, masks, ruler and a computer equipped with Microsoft Excel. Materials used in the research were organic solid waste from the traditional market, BSF larvae, acrylic board, gauze pads, trash bag, iron wire, plastic rope, and nails.

Sample material was undergone by heating it at $105^{\circ} \mathrm{C}$ for 24 hours to obtain $\mathrm{pH}$ and water content. The standard procedure to analyze the protein content of BSF larvae is the Kjeldahl method. Determination of protein content was measured at the age of larvae 14 days (according to the age of larvae at its highest protein content) and pupae stage in several types of domestic organic waste in Bogor Municipality. Protein content testing was conducted at the Food and Feed Laboratory of SEAMEO BIOTROP. Several calculations were carried out to describe the characteristic, i.e. the change of larva weight, reduction percentage, waste reduction index (WRI) fresh matter consumption rate (FMCR), and dry matter consumption rate (DMCR). According to [1], the relationship between waste reduction rate of BSF larva and waste reduction index (WRI) is presented in Eq. (1).

$$
W R I=\frac{D}{t} \times 100 \%
$$

Notes:

WRI $=$ waste reduction index $(\% /$ day $)$

$\mathrm{D}=$ waste reduction rate $(-)$

$\mathrm{t}=$ acquired time for waste decomposition (day).

The daily consumption rate of waste is calculated based on the dry weight of the organic waste [1], which is the fresh matter consumption rate (FMCR) as presented in Eq. (2).

$$
F M C R=\frac{a / b}{c}
$$


Notes:

FMCR = daily consumption rate of fresh organic waste (mg/larva/day)

$\mathrm{a}=$ amount of added waste $(\mathrm{mg})$

$\mathrm{b}=$ duration of addition (days)

$\mathrm{c}=$ amount of larva (larva).

Based on the total mass of organic waste added during the larva phase and weight of waste residue at the final of the cycle, the dry matter reduction (DMR) is calculated in per cent by using Eq. (3).

$$
\% D M R=\frac{j-k}{k} x 100 \%
$$

Remark:

$\% \mathrm{DMR}=$ dry material reduction

$\mathrm{j}=$ initial dry weight of organic waste

$\mathrm{k}=$ final dry weight of organic waste

The DMCR (dry matter consumption rate) that is used in the design of the planned decomposition facility is calculated by using Eq. (4).

$$
D M C R=\frac{F M C R \times \% D M R}{100}
$$

Notes:

$\mathrm{DMCR}=$ dry matter consumption rate

$\mathrm{FMCR}=$ fresh matter consumption rate

$\% \mathrm{DMR}=$ per cent dry matter reduction.

Larvae length and weight measurements were carried out by randomly selecting 30 larvae in each replication. Measurements were carried out after the $12^{\text {th }}$ day when the difference in larval size and weight changed significantly.

Palatability test on the BSF larvae using cafeteria feeding method on broiler DOC were observed based on feeding trial on several types of commercial feed with BSF larvae meal, the observed variables including feed consumption and body weight of DOC broilers. Feed ingredients are weighed according to the given treatment. Corn flour, BSF larva flour, MBM flour and soybean meal flour, fish meal, CGM flour were weighted as much as 1000 grams, whereas lime and DCP 150 grams. Drinking water was provided in the ad libitum drinking area. DOC weight gain measurements and feed reduction were measured once a week. Feed consumption is calculated using Eq. (5) and (6).

$$
\begin{gathered}
\text { Feed Consumption }=\text { Initial Feed Weight (grams) } \\
\text { - Remaining Feed (grams) }
\end{gathered}
$$

$$
=\frac{\begin{array}{c}
\text { Feed consumption per day } \\
\text { consumption during breeding }\left(\frac{\text { gram }}{\text { head }}\right)
\end{array}}{\text { Duration of breeding }(\text { days })}
$$

The cage used in this study was a litter system, one with rice husk as its base. The slat type enclosure is divided into four experimental units, and each trial unit has a size of $0.7 \times 0.7 \times 0.7$ meters with each experiment unit containing six chickens. Each cage is equipped with feed and drinking water container that were easily accessible by chickens. The pen used four pieces of 75-watt bulb lamps. The equipment used were baby chick feeder, hanging bottle, curtain enclosure, wastepaper, lights, dipper, buckets, scales, measuring cups, thermometers, bamboo for the cage bulkhead and label paper used for the identification of cages.

\section{Results and Discussion}

BSF larvae can develop in many countries. Optimal environmental conditions for larvae are as follows [17]. In a warm climate area, the ideal temperature is about $24-30^{\circ} \mathrm{C}$. If it is too low, the larva's metabolism slows down. As a result, the larvae eat less so that their growth becomes slower than the normal one. In a shaded environment, larvae avoid light and always look for a shady environment and away from sunlight. If the food source is exposed to light, the larvae move to deeper layers of food sources to avoid the light. Active larvae of Hermetia illucens develop in relative humidity (RH) about $70-80 \%$ and become under-developed due to drought, lack of food or lack of oxygen. Physical resistance of BSF larvae causes the survival of the species as a whole [18].

\section{Temperature Variation}

Position on the equator causes Indonesia experiences warm temperatures throughout the year. The average surface temperature at zero altitudes (coastline) is generally above $25^{\circ} \mathrm{C}$. In 2016 the average temperature ranged about $23.8-28.4^{\circ} \mathrm{C}$. The minimum temperature varies about $17.2-28.0^{\circ} \mathrm{C}$ with the lowest minimum temperature recorded at the West Lombok Observation Station in West Nusa Tenggara Province. The maximum temperature reaches $29.8-36.8^{\circ} \mathrm{C}$, where the highest maximum temperature was recorded at Kayuwatu Observation Station in North Sulawesi. The average temperature data was collected from selected locations in Java Island along with research sites considering the temperature distribution. Java Island was chosen since it is the key to the Indonesian economy and is the most densely populated island in Indonesia. Recapitulation of temperature data in provinces of Java Island during 2018 is compiled in Table 1.

The average temperature in Java in 2019 was $26.9^{\circ} \mathrm{C}$ with a minimum average temperature of $21.4^{\circ} \mathrm{C}$, and the maximum average temperature was $34.2^{\circ} \mathrm{C}$. Recapitulation of temperature data is also carried out in 20 cities or districts in Java, as presented in Table 2.

Based on Table 2, regencies and municipalities were classified into three groups, i.e. those with low temperature, moderate and high temperatures. Cities/regencies with low temperatures ranging from $23-26^{\circ} \mathrm{C}$ are Cianjur Regency, Batu Municipality, 
Table 1. Recapitulation of temperature data in Java Island provinces [19].

\begin{tabular}{|c|c|c|c|c|}
\hline \multirow{2}{*}{ No } & \multirow{2}{*}{ Province } & \multicolumn{3}{|c|}{ Temperature $\left({ }^{\circ} \mathrm{C}\right)$} \\
\cline { 3 - 5 } & & Minimum & Maximum & Average \\
\hline 1 & DKI Jakarta & 23.2 & 35.0 & 28.6 \\
\hline 2 & West Java & 18.2 & 32.2 & 23.3 \\
\hline 3 & Central Java & 24.0 & 34.6 & 28.1 \\
\hline 4 & DI Yogyakarta & 18.4 & 34.8 & 26.1 \\
\hline 5 & East Java & 20.7 & 35.8 & 28.1 \\
\hline 6 & Banten & 23.9 & 32.5 & 27.2 \\
\hline \multicolumn{2}{|c|}{ Average } & 21.4 & 34.2 & 26.9 \\
\hline
\end{tabular}

Cimahi Regency, Bandung Municipality, Surakarta Municipality, Sukabumi Regency. Cities/regencies with moderate weather ranging from $26-28^{\circ} \mathrm{C}$ are Yogyakarta, Lumajang Regency, Semarang Municipality, Bogor Municipality, Magetan Regency, Serang Regency, Tangerang Municipality, Lebak Regency, South Tangerang Municipality, Tegal Municipality and Sukabumi Regency. Cities/regencies with high temperature ranging between $28-30^{\circ} \mathrm{C}$ are Cilegon Municipality, Cirebon Municipality, Jakarta, and Surabaya Municipality.

The studies on the decomposition characteristics of organic solid wastes under different temperature variations were carried out in three separate compartments, namely A, B, and C. Compartment "A" represents the low-temperature regime, compartment "B" represents medium temperature. In contrast, compartment " $\mathrm{C}$ " represents a high-temperature regime. Setting up the low temperature was by using air conditioning $(\mathrm{AC})$ unit, while the high-temperature setting was reached by using a heating unit (heater). The recorded temperature and relative humidity in compartments A, B, and C are presented in Table 3.

The organic solid waste used came from the Bogor Market, with a total weight of waste given over 14 days, $41 \mathrm{~kg}$. BSF larvae eggs used were 15 grams per compartment. The number of eggs used is based on the calculation of the amount of waste. Differences in daily organic solid waste reduction in the three compartments are presented in Fig. 1.

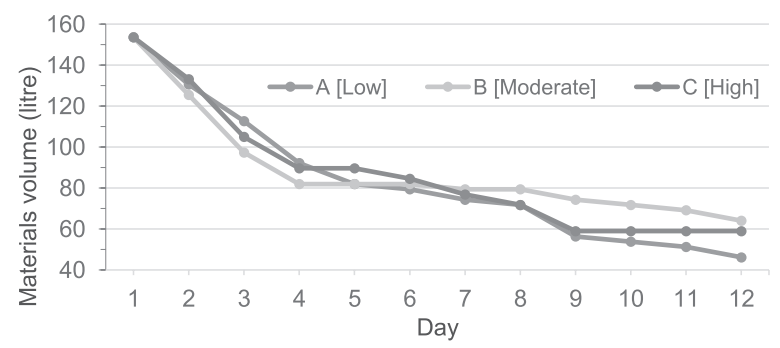

Fig. 1. Reduction of waste volume versus temperature variation.

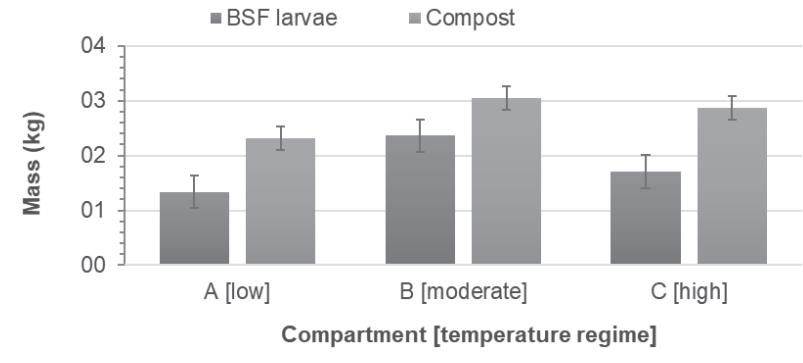

Fig. 2. Products resulted from three compartments.

The best waste reduction is found in low temperatures, namely compartment $\mathrm{A}$, the next best reduction in waste is in high temperatures, and the waste reduction is less significant at moderate temperatures. The product mass resulted from the three compartments is presented in Fig. 2.

At significantly different temperature variation, BSF larvae were still able to develop quite nicely. The range of compost reduction values did not differ considerably between compartments. Products are produced at different temperature variation. The results of the decomposition of organic solid waste using BSF larvae have several products, namely residues, compost, and larvae.

The number of BSF larvae harvested ranged from 2320.8-2865.1 grams. It indicates that BSF larvae can develop well at several different temperatures. It is consistent with the previous findings [1] that BSF larvae are species that are very resistant to various environmental conditions, such as temperature variation. The reduction percentage of the three compartments A, B, and C were $91.2 \%, 87.0 \%$, and $89.0 \%$, respectively. The per cent reduction produced at some temperature conditions is presented in Fig. 3.

The test results of the compost quality are presented in Table 5. Compost quality analysis at different temperature is compared with the national standard of SNI 19-7030-2004 concerning Compost Specifications from Domestic Organic Waste [21]. The parameters tested were 13 units. These parameters consist of physical parameters, macro-elements, micro-elements, and other elements.

Based on the test results, all parameters meet the quality standards except the $\mathrm{C} / \mathrm{N}$ ratio. It proves that

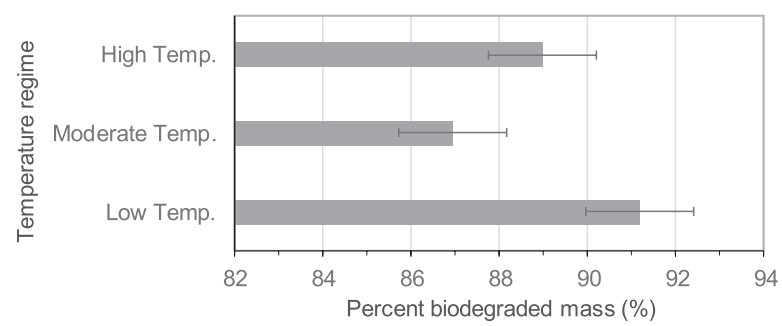

Fig. 3. Per cent biodegraded mass at different temperature. 
Table 2. Recapitulation of temperature data in 20 municipalities or regencies in Java [20].

\begin{tabular}{|c|c|c|c|c|}
\hline \multirow{2}{*}{ No } & \multirow{2}{*}{ Regency/Municipality } & \multicolumn{3}{|c|}{ Temperature } \\
\hline & & Maximum $\left({ }^{\circ} \mathrm{C}\right)$ & Minimum $\left({ }^{\circ} \mathrm{C}\right)$ & Average $\left({ }^{\circ} \mathrm{C}\right)$ \\
\hline \multicolumn{5}{|c|}{ Low temperature } \\
\hline 1 & Cianjur Regency & 26.8 & 20.0 & 21.0 \\
\hline 2 & Batu Municipality & 27.0 & 19.0 & 23.0 \\
\hline 3 & Cimahi Municipality & 26.0 & 20.0 & 23.5 \\
\hline 4 & Bandung Municipality & 30.5 & 18.8 & 23.8 \\
\hline 5 & Surakarta Municipality & 33.5 & 15.1 & 24.3 \\
\hline 6 & Sukabumi Regency & 30.0 & 18.0 & 24.9 \\
\hline & Average & 29.0 & 18.5 & 23.4 \\
\hline \multicolumn{5}{|c|}{ Moderate temperature } \\
\hline 7 & Yogyakarta & 26.7 & 25.1 & 26.2 \\
\hline 8 & Lumajang Regency & 34.5 & 18.9 & 26.7 \\
\hline 9 & Semarang Municipality & 31.8 & 21.7 & 26.8 \\
\hline 10 & Bogor Municipality & 33.0 & 22.2 & 27.3 \\
\hline 11 & Magetan Regency & 31.0 & 24.0 & 27.5 \\
\hline 12 & Serang regency & 32.4 & 23.9 & 27.5 \\
\hline 13 & Tangerang Municipality & 32.5 & 23.4 & 27.7 \\
\hline 14 & Lebak Regency & 33.1 & 22.1 & 25.4 \\
\hline 15 & $\begin{array}{c}\text { South Tangerang Mu- } \\
\text { nicipality }\end{array}$ & 32.2 & 24.3 & 27.7 \\
\hline 16 & Tegal Municipality & 28.9 & 26.6 & 27.9 \\
\hline & Average & 31.6 & 23.2 & 27.1 \\
\hline \multicolumn{5}{|c|}{ High temperature } \\
\hline 17 & Cilegon Municipality & 32.4 & 23.9 & 28.2 \\
\hline 18 & Cirebon Municipality & 34.5 & 23.3 & 28.5 \\
\hline 19 & Jakarta & 35.0 & 23.2 & 28.6 \\
\hline \multirow[t]{3}{*}{20} & Surabaya Municipality & 33.8 & 24.5 & 29.2 \\
\hline & Average & 33.9 & 23.7 & 28.6 \\
\hline & Overall average & 31.3 & 21.9 & 26.3 \\
\hline
\end{tabular}

the results of compost from different temperatures have quite good results when compared with SNI 197030-2004 on Compost Specifications from Domestic Organic Waste. There needs to be an increase in the

Table 3. Daily average temperature and relative humidity in three compartments.

\begin{tabular}{|c|c|c|c|}
\hline \multirow{2}{*}{ Parameter } & \multicolumn{3}{|c|}{ Compartment } \\
\cline { 2 - 4 } & A [low] & B [moderate] & C [high] \\
\hline Temperature $\left({ }^{\circ} \mathrm{C}\right)$ & 21 & 26 & 29 \\
\hline RH $(\%)$ & 72 & 74 & 72 \\
\hline
\end{tabular}

value of carbon $(\mathrm{C})$ so that the value of the $\mathrm{C} / \mathrm{N}$ ratio can meet quality standards.

According to [16], larval protein levels can reach up to $40 \%$. Through different temperatures, the levels of protein in the larvae body are analyzed. Measurement of protein content using the Kjeldahl method on a wet basis. The results of analyses of protein content are presented in Table 4.

Protein sources from BSF larvae can be used for animal feed is a promising alternative feed (Salomone et al., 2017). Based on Table 5, wet base protein levels ranged from $8.9-17.1 \%$. BSF larvae in compartment B have the highest value of protein content. 
Table 4. Results of protein content analysis at several temperatures variations.

\begin{tabular}{|c|c|c|}
\hline No. & Temperature regime & Protein Content (\%) \\
\hline 1 & Low Temperature & 8.9 \\
\hline 2 & Moderate Temperature & 17.1 \\
\hline 3 & High Temperature & 15.9 \\
\hline
\end{tabular}

\section{Characteristics of BSF Larvae Decomposition in Several Types of Waste}

BSF larvae can eat a variety of food waste in a variety of flavours. BSF larvae can be given a variety of feed, including kitchen waste, fruits, vegetables, liver, fish waste, urban waste, human waste, and animal waste. The flexibility of BSF larvae feed can be an ideal insect in producing protein. However, differences in feed can affect the development process of BSF larvae. So, the right formulation is needed in feeding the BSF larvae to maximise production and efficiency. Some microbes that are used as a pre-treatment process can improve the digestive ability of BSF larvae, the process of larval development, and increase the mass of the prepupa stage [9].

Determination of water content of waste at the beginning of the study was done through the Gravimetric Method through heating at $105^{\circ} \mathrm{C}$ for 24 hours. The recommended optimum moisture content is $60-90 \%$ [1]. The results of measurements of water content are presented in Fig. 4.

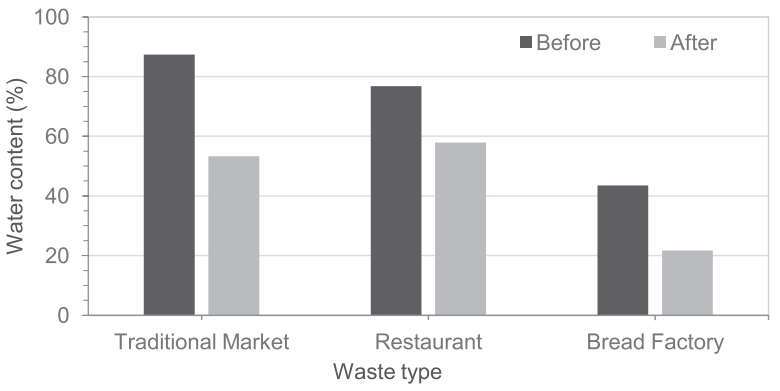

Fig. 4. The water content of the organic wastes.

Organic wastewater content given to BSF larvae is still in the optimal range of $60-90 \%$. The type of waste used is based on the results of a survey with several BSF larva business players. The three types of waste used are restaurant waste, market waste, and bread factory waste. The given waste is given the same treatment, which is ground with a grinding machine so that the waste conditions are homogeneous.

The fungus in the optimum growth of garbage at $\mathrm{pH}$ 5.6, but still can survive at $\mathrm{pH}$ 2.0-9.0 [22] The results of $\mathrm{pH}$ measurements on organic solid waste used are presented in Fig. 5. Based on Fig. 5, the pH range of organic waste in the initial conditions given to BSF larvae ranged from 3.83-3.59. The $\mathrm{pH}$ range of organic waste in the final conditions given to BSF larvae increased from before, which ran from 5.98-5.32. It indicates that the decomposition process is going well. BSF larvae have a broad enough $\mathrm{pH}$ tolerance range so that BSF larvae can live in extreme

Table 5. Compost quality from different temperature regime.

\begin{tabular}{|c|c|c|c|c|c|}
\hline \multirow{2}{*}{ Parameter } & \multirow{2}{*}{ Unit } & \multirow{2}{*}{ Standard ${ }^{\mathrm{a}}$} & \multicolumn{3}{|c|}{ Temperature regime } \\
\hline & & & Low & Moderate & High \\
\hline Temperature & ${ }^{\circ} \mathrm{C}$ & GW temp. ${ }^{b}$ & 27.8 & 28.2 & 28.0 \\
\hline Colour & - & black & Black & black & black \\
\hline Nitrogen $(\mathrm{N})$ & $\%$ & $>0.4$ & 3.4 & 3.4 & 4.0 \\
\hline Carbon (C) & $\%$ & $9.8-32$ & 23 & 25 & 31 \\
\hline Phosphor $\left(\mathrm{P}_{2} \mathrm{O}_{5}\right)$ & $\%$ & $>0.1$ & 0.71 & 0.53 & 0.6 \\
\hline C/N Ratio & - & $10-20$ & $7^{\mathrm{c}}$ & $7^{\mathrm{c}}$ & $8^{c}$ \\
\hline Potassium $\left(\mathrm{K}_{2} \mathrm{O}\right)$ & $\%$ & $>0.22$ & 5.67 & 4.63 & 3.82 \\
\hline Cobalt (Co) & ppm & $<34$ & 3.5 & 2.5 & 1.9 \\
\hline Zinc (Zn) & ppm & $<500$ & 146 & 122 & 123 \\
\hline Calcium $(\mathrm{Ca})$ & $\%$ & $<25.5$ & 3.6 & 3.0 & 2.9 \\
\hline Magnesium (Mg) & $\%$ & $<0.6$ & 0.5 & 0.4 & 0.4 \\
\hline Iron $(\mathrm{Fe})$ & $\%$ & $<2.0$ & 0.6 & 0.4 & 0.3 \\
\hline Manganese (Mn) & $\%$ & $<0.1$ & 0.03 & 0.02 & 0.03 \\
\hline
\end{tabular}

${ }^{\text {a }}$ SNI 19-7030-2004 on Compost Specifications from Domestic Organic Waste; ${ }^{b} \mathrm{GW}=$ groundwater

${ }^{\mathrm{c}}$ Uncomply with standard 


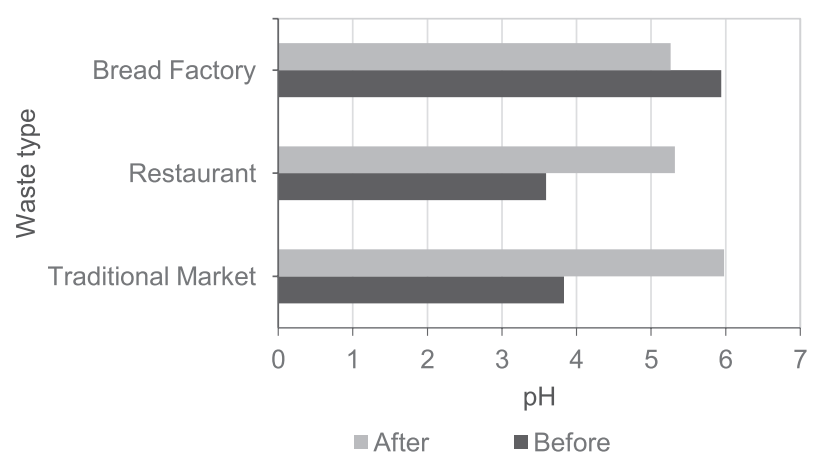

Fig. 5. $\mathrm{pH}$ of the wastes before and after biodegradation process.

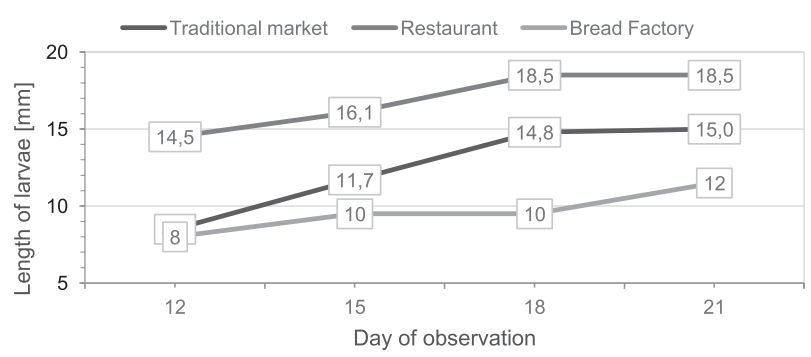

Fig. 6. Changes in length of larvae.

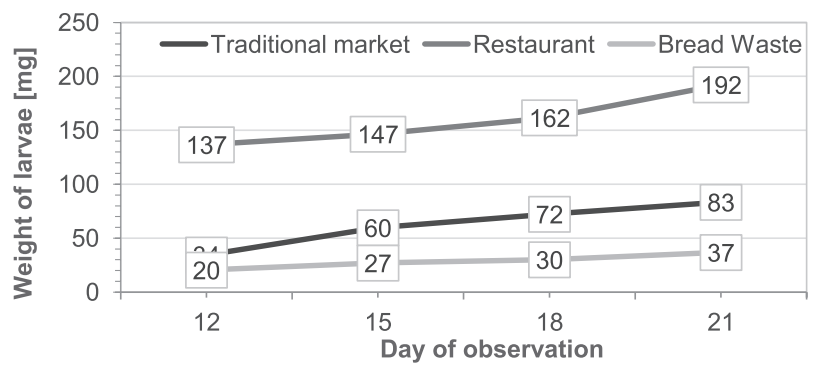

Fig. 7. The measurement result of changes in larval weight.

environmental conditions [23]. The high activity of microorganisms in the waste can increase and decrease in $\mathrm{pH}$ values [24].

Measurement of length and weight of larvae aims to determine differences in larval development in several different types of waste. Measurements were made by randomly selecting 30 larvae in each replication. Measurements were made after the $12^{\text {th }}$ day when the difference in larval length and weight changed significantly. The results of analyses of changes in larval size are presented in Fig. 6. Based on Fig. 6, it shows that BSF larvae fed by restaurant waste have faster growth in weight compared to the traditional market waste and bread factory waste. The results of measurements of larval weight changes are presented in Fig. 7.

According to Fig. 7, the change in larvae weight in restaurant waste increases rapidly compared to the traditional market waste and bread factory waste. BSF larvae which were fed in the form of restaurant waste on the $21^{\text {st }}$ day of observation weighed $192 \mathrm{mg}$ per head, with a length of $18.5 \mathrm{~mm}$.

The decomposition character is an essential factor in the processing of organic waste by BSF larvae. Several parameters determine the characteristic of organic waste decomposition by BSF larvae. These parameters consist of per cent reduction, WRI, FMCR, per cent DMR, DMCR, and larvae weight harvested from each type of organic waste that has been observed for 21 days of observation by repeating as many as six times per waste type. The parameter values for the characteristics of organic waste decomposition by BSF larvae are presented in Table 6.

WRI shows the ability of BSF larvae to consume organic waste by considering the time or period of administration. A high WRI value means that the larva's ability to reduce organic waste is high [16]. The amount of fresh matter consumption rate (FMCR) states the total weight of food that can be consumed per larvae per day in a fraction of fresh matter (wet). Table 6 provides information that the highest per cent reduction value is found in traditional market waste at $86 \%$. The highest WRI was found in restaurant waste (4.09\%/day). Restaurant waste has optimal water content for larval growth so that the decomposition speed is the highest. The value of fresh matter consumption rate (FMCR) is at a constant amount because it has a continuous wet weight during administration.

The percentage of dry matter rate (DMR) is obtained based on the reduction of waste in dry matter. Based on Table 6, the lowest DMR per cent value is found in bread waste samples. The DMR per cent value is a correction for the determination of the dry matter consumption rate (DMCR) as a benchmark for facility design based on the number of larvae used. DMCR values, the weight of larvae that can be harvested, protein content and fat content of larvae are presented in Table 7.

The highest DMCR was found in restaurant waste $33.3 \mathrm{mg} /$ larvae/day. DMCR value is used as a design for the provision of organic waste in the process of decomposition of urban organic waste. The results

Table 6. Per cent reduction, DMR, WRI, FMCR on several types of waste.

\begin{tabular}{|c|c|c|c|c|}
\hline Source of Organic Waste & Reduction $(\% \mathrm{WW})$ & DMR $(\%)$ & WRI (\%/day) & FMCR (mg/larvae/day) \\
\hline Traditional Market & 86 & 48 & 3.0 & \multirow{2}{*}{50.9} \\
\hline Restaurant & 81 & 65 & 4.1 & \\
\hline Bread Factory & 70 & 58 & 3.6 & \\
\hline
\end{tabular}


Table 7. DMCR values, the weight of larvae harvested, protein content and the fat content of larvae.

\begin{tabular}{|c|c|c|c|}
\hline \multirow{2}{*}{ Parameter } & \multicolumn{2}{|c|}{ Source of Organic Waste } \\
\cline { 2 - 4 } & Traditional Market & Restaurant & Bread Factory \\
\hline DMCR (mg/larva/day) & $24.3 \pm 1.6^{\mathrm{c}}$ & $33.3 \pm 1.7^{\mathrm{a}}$ & $29.4 \pm 1.0^{\mathrm{b}}$ \\
\hline Mean of harvested larvae per unit (kg) & $3.28 \pm 0.25^{\mathrm{b}}$ & $3.69 \pm 0.41^{\mathrm{a}}$ & $2.04 \pm 0.17^{\mathrm{c}}$ \\
\hline Mean of protein content (\%) & $12.9 \pm 0.3^{\mathrm{c}}$ & $33.9 \pm 5.9^{\mathrm{a}}$ & $23.2 \pm 1.6^{\mathrm{b}}$ \\
\hline Mean of fat content (\%) & $2.9 \pm 0.6^{\mathrm{b}}$ & $13.3 \pm 1.9^{\mathrm{a}}$ & $1.2 \pm 0.5^{\mathrm{c}}$ \\
\hline
\end{tabular}

* Superscript letters indicate that the data are significantly different $(\mathrm{P}<0.01)$

Table 8. Cafeteria test results.

\begin{tabular}{|c|c|c|c|c|}
\hline Types of Feed & $\begin{array}{c}\text { Total consumption } \\
\text { (gram) }\end{array}$ & $\begin{array}{c}\text { Daily Average Consumption } \\
\text { (gram/chicken/day) }\end{array}$ & $\begin{array}{c}\text { Consumption Percentage } \\
\text { (\%) }\end{array}$ & Order of Preference \\
\hline BSF & 674.2 & 8.1 & 25.5 & 1 \\
\hline Corn Gluten Meal & 594.3 & 7.0 & 22.3 & 2 \\
\hline Meat Bone Meal & 550.1 & 6.8 & 21.6 & 3 \\
\hline Soybean Meal & 438.2 & 5.4 & 17.1 & 5 \\
\hline Corn & 290.6 & 3.4 & 1.2 & 6 \\
\hline Fish Flour & 29.4 & 0.4 & 0.9 & 7 \\
\hline Calcium Carbonate & 26.0 & 0.3 & 0.6 & 8 \\
\hline Dicalcium Phosphate & 21.7 & 0.2 & & 5 \\
\hline
\end{tabular}

of compost analysis of the three types of organic waste meet SNI 19-7030-2004 standards on Compost Specifications from Domestic Organic Waste except for $\mathrm{C} / \mathrm{N}$ ratio.

\section{Palatability Test for BSF Larvae Flour on DOC Broilers (Cafetaria Test)}

Based on the cafeteria test, it can be known the preferred level of DOC of broiler chickens to five (5) types of protein sources that have been tested. The cafeteria test result is presented in Table 8. Cafeteria test uses five types of protein sources, namely BSF larvae flour, MBM flour, soybean meal flour, fish meal, and CGM, carbohydrate sources namely corn, and mineral sources namely lime and DCP.

Based on Table 8, during 14 days of observation of DOC broiler chickens, the first preference order is BSF flour with a percentage of consumption of 25.5. The average yield of consumption (ration, \% BB, consumption PK, SK, LK, ) broiler DOC during the study is presented in Table 9.

Based on Table 9, it is known that the average consumption of broiler chicken DOC ratio from the age of 1-14 days is 31.6 grams/chicken/day, with the per cent consumption of body weight of $17.9 \%$. The average use of crude protein is 13.37 grams/chicken/day, the average consumption of crude fibre is 1.16 grams/chicken/day,
Table 9. Average DOC consumption of broiler chickens during the study.

\begin{tabular}{|c|c|}
\hline Parameter & Average \\
\hline Ration Consumption (grams/chicken/day) & $31.6 \pm 5.8$ \\
\hline Consumption (\% Body Weight) & $17.9 \pm 2.5$ \\
\hline Crude Protein Consumption (grams/chicken/day) & $13.37 \pm 2.06$ \\
\hline Crude Fibre Consumption (grams/chicken/day) & $1.16 \pm 0.33$ \\
\hline Crude Fat Consumption (grams/chicken/day) & $3.32 \pm 1.22$ \\
\hline
\end{tabular}

and an average consumption of crude fat is 3.32 grams/ chicken/day.

\section{Conclusions}

The conclusions that can be drawn from the research are as follows:

1. Reduction of waste is best at low temperatures, compartment $\mathrm{A}$, based on compost testing results, all parameters meet quality standards except the $\mathrm{C} / \mathrm{N}$ ratio. Wet base protein levels ranged from $8.9-17.1 \%$

2. In the waste type variant, the most significant change in larval length and weight was found in the type of restaurant waste. The highest DMCR value was 
found in the kind of restaurant waste $33.3 \mathrm{mg} /$ larvae/ day.

3. Giving BSF larvae flour in DOC broiler has a preference sequence number 1 among other feeds with a percentage of consumption of $25.5 \%$ of the total feed. The preferred level of DOC broiler against BSF flour has an excellent response so that BSF larvae have great potential to be converted into the feed.

4. Compost resulted from solid organic waste meets all parameters as stipulated in national standard, except the $\mathrm{C} / \mathrm{N}$ ratio parameter.

\section{Acknowledgements}

The research was supported financially by the Ministry of Research and Technology, the Republic of Indonesia, organised by The Institute of Research and Community Services, IPB University (LPPM-IPB). Authors wish to thank all the analysts in The Service Laboratory of SEAMEO BIOTROP for their helpful sample analysis.

\section{Conflict of Interest}

The authors declare no conflict of interest.

\section{References}

1. DIENER S., SOLANO N.M., GUTIÉRREZ F.R., ZURBRÜGG C.T. Biological Treatment of Municipal Organic Waste using Black Soldier Fly Larvae. W Biomass Valor, 2 (1), 357, 2011.

2. MANI S., SINGH A. Sustainable municipal solid waste management in India: a policy agenda. Procedia Environmental Sciences, 35 (1), 150, 2016.

3. VARMA V.S., DAS S., SASTRI C.V., KALAMDHAD A.S. Microbial degradation of lignocellulosic fractions during drum composting of mixed organic waste. Sustainable Environment Research, 27 (2), 265, 2017.

4. KANWAL S., IRAM S., KHAN M., AHMAD I. Aerobic composting of water lettuce for preparation of phosphorus enriched organic manure. African Journal of Microbiology R, 5 (14), 1784, 2011.

5. MORALES-RAMOS, ROJAS G., SHAPIRO-ILAN D.I. Mass Production of Beneficial Organisms Invertebrates and Entomopathogens. Academic Press, San Diego, USA, 18, 2014.

6. MAKKAR H.P., TRAN G., HEUZÉ V., ANKERS P. State-of-the-art on use of insects as animal feed. Anim. Feed Sci. Tech, 197 (1), 1, 2014.

7. SMETANA S., PALANISAMY M., MATHYS A., HEINZ V. Sustainability of insect use for feed and food: life cycle assessment perspective. J. Clean Prod, 137(1), 741, 2016.
8. POPA R, GREEN T. Biology and Ecology of the Black Soldier Fly. Diptera LCC e-Book, Amsterdam, The Netherlands, 19, 2012.

9. WANG Y.S., SHELOMI M. Review of black soldier fly (Hermetia illucens) as animal feed and human food. Journal of Foods, 6 (21), 1, 2004.

10. GUERERO L.A., MAAS G., HOGLAND W. Solid Waste Management Challenges for Cities in Developing Countries- Review. W Management J, 33 (1), 220, 2013.

11. LOHRI C.R., DIENER S., ZABALETA I., MERTENAT A., ZURBRÜGG C. Treatment technologies for solid urban biowaste to create value products: a review with a focus on low-and middle-income settings. Env Sci Bio, 16 (1), 81, 2017.

12. MYERS H.M., TOMBERLIN J.K., LAMBERT B.D., KATTES D. Development of black soldier fly (Diptera: Stratiomyidae) larvae fed dairy manure. Env Entomol, 37 (1), 11, 2008.

13. HENRY M., GASCO L., PICCOLO G., FOUNTOULAKI E. Review on the use of insects in the diet of farmed fish: past and future. Anim. Feed Sci. Tech, 203 (1), 1, 2015.

14. DIENER S., ZURBRUGG C., TOCKNER K. Conversion of organic material by black soldier fly larvae: establishing optimal feeding rates. W. Manage. Res, 27 (1), 603, 2009.

15. SALOMONE R., SAIJA G., MONDELlO G., GIANNETTO A., FASULO S., SAVASTANO D. Environmental impact of food waste bioconversion by insects: application of life cycle assessment to process using Hermetia illucens. J. Clean Prod, 140 (1), 890, 2017.

16. DIENER S. Valorisation of Organic Solid Waste using the Black Soldier Fly, Hermetia illucens, in Low and MiddleIncome Countries. PhD Dissertation. ETH Zurich, Zurich, Switzerland, 2010.

17. DORTMANS B.M.A., DIENER S., VERSTAPPEN B.M., ZURBRÜGG C. Black Soldier Fly Biowaste Processing A Step-by-Step Guide. Eawag Swiss Federal Institute of Aquatic Science and Technology, Dübendorf, Switzerland, 100, 2017.

18. YUWONO AS, MENTARI PD. Utilisation of Black Soldier Fly (BSF) Larvae in Organic Waste Treatment (in Indonesian). SEAMEO BIOTROP, Bogor, Indonesia, 98, 2018.

19. Statistics Indonesia. Statistical Yearbook of Indonesia. BPS-Statistics Indonesia, Jakarta, Indonesia, 762, 2018.

20. Statistics Indonesia. Statistical Yearbook of Indonesia. BPS-Statistics Indonesia, Jakarta, Indonesia, 782, 2019.

21. BSN National Standardization Agency (In Indonesia). Specifications for Compost from Domestic Organic Waste (in Indonesian). SNI 19-7030-2004. BSN, Jakarta, Indonesia, 2004.

22. TCHOBANOGLOUS G., KREITH F. Handbook of Solid Waste Management-Second Edition. Mc Graw-Hill Companies Inc, New York. 2002.

23. SUCIATI R., FARUQ H. The effectiveness of Hermetia illucens maggots (black soldier fly) as a solution to the utilisation of organic waste (in Indonesia). Journal of Biosphere and Biological Education (in Indonesia), 2 (1), 8, 2017.

24. GAUDY AF, GAUDY ET. Microbiology for Environmental Engineering Scientist and Engineers. John Wiley \& Sons Inc, New York, USA, 736, 1980. 
